\title{
Encrusting protected reef Hon Nai in Cam Ranh Bay in the South China Sea
}

\author{
Yuri Ya. Latypov
}

A. V. Zhirmunsky Institute of Marine Biology, FEB-RAS, Vladivostok, Russia; 1 tpv@,mail.ru

Received 29 October 2011; revised 30 November 2011; accepted 13 December 2011

\begin{abstract}
A protected non-structural reef in Cam Ranh Bay in southern Vietnam was surveyed. A high diversity was found among scleractinian and accompanying mass species of macrobenthos. Thirtyfour species were identified only among genera Acropora; it made $80 \%$ of the total composition of these Scleractinian on reefs of Vietnam and a quarter of the total abundance of these corals on reefs in the Indo-Pacific. A new species, Favites camranensis sp. nov, earlier unknown for science, has been found. The vertical bionomic zonality corresponding to zonal distribution of environmental factors on the reef under study is similar to that on reefs of the Siam Bay, different regions of the Pacific and the Caribbean Basin. Expansion of prosperous state of the reef and minimization of anthropogenic influence on some reefs of Vietnam had a positive effect on their state. It is supposed, that the reef at Hon Nai Island is obliged by the prosperity to security measures and minimization of the anthropogenous influence, provided with the decision of government SRV and company "Sanest".
\end{abstract}

Keywords: Vietnam; Conservation Measures; Reefs; High Biodiversity; New Species;

Scleractinian

\section{INTRODUCTION}

Hon Nai Island, situated 11 kilometers east of the Cam Ranh coast, is formed of large-blocks of dacite. The island stretches from north to south slightly over $0.8 \mathrm{~km}$ long $\left(12^{\circ} 03^{\prime} 50^{\prime \prime} \mathrm{N}, 109^{\circ} 19^{\prime} 60^{\prime \prime} \mathrm{E}\right.$ and $\left.12^{\circ} 02^{\prime} 75^{\prime \prime} \mathrm{N}, 109^{\circ} 19^{\prime} 70^{\prime \prime} \mathrm{E}\right)$, surrounded by a sandy platform, 6 - 15 mdeep eastwardand 9 - 20 mdeep westward. Indigenous island daciteboulder piles extend as stripes $5-20 \mathrm{~m}$ wide from southwest to northeast. Coral settlements are distributed mainly on the outputs of the underwater island dacite and to a lesser extent on the corallogenous ruins of not exceeding a meter in diameter. The island is owned by the company "Sanest", there is a restricted if any at all access to the underwater resources. A visually coral ecosystem formed at the southwest of the island is distinguished by an amazing purity of the surrounding waters and a surpriseingly high species diversity of reef-building corals and other accompanying animals, which significantly distinguishes it from the adjacent Mainland and island reefs $[1,2]$. By the specificity of geomorphological and climate conditions, Vietnam's adjacent reefs are clearly distinguished into two types. The first type includes the reefs with a distinct zonation (reef lagoon, reef-flat, etc.) with a developed carbonate framework, so-called structural reefs [3] that are common for the tropical zone of the World Ocean. Reefs of the second type display a weak morphostructural zonation, with some zones occasionally absent. Carbonate deposits in such reefs comprise only coral settlements of a low thickness, hardly changing the overall substrate profile. These are so-called structureless or encrusting reefs [4]. Given the seemingly unusual wealth now on reef Hon Nai it seems relevant here the results of the study species composition and distribution characteristics of Scleractinian and related macrobenthos.

Coral reefs of Vietnam are an integral part of IndoWest pacific tropic center of origin and diversity of corals [2]. They represent a very productive natural ecosystem with a variety of ecological niches and multiple inhabitants. At the same time, coral reefs serve as a basis for many branches of economy (fishery, construction works, SCUBA diving, etc.). They form a natural barrier against destructive energy of waves, protecting coastline from erosion. Coral reef is actually a living barrier, which permanently replaces its destroyed basis due to its growth. Besides, coral reefs through their erosion serve as a main source of sand, replenishing critically eroded coasts. Results of hydrobiological studies on coastal Mainland and the island reefs of Vietnam in recent years clearly demonstrated their biodegradable, largely due to strong anthropogenic press $[1,2,4]$. Study of protected and best preserved reef is necessary to determine it's damage and to develop recommendations for the restoration and preservation of disturbed communities of reef. 


\section{MATERIAL AND METHODS}

SCUBA-diving equipment was used to study composition and distribution of Scleractinian corals and mass species of macrobenthos, community structure in every reef zone (Figure 1). Generally accepted hydrobiological methods were applied with the use of counting frames and transect $[5,6]$. The abundance of mass species of mollusks and echinoderms, branching, massive, encrusting and funnel form Scleractinian colonies, as well as the degree of coral covering of the substrate were assessed along 100-meter transect with the use of a frame divided into 100 quadrants of $10 \mathrm{~cm}^{2}$. Number mass a species of mollusks and echinoderms counted up on the area of 5 $\mathrm{sq} \cdot \mathrm{m}$. Depth of a structure transects was fixed diving depth meter "Seemann Sub". The transects were guided on topographical features: capes, tops of hills, etc. Reef landscapes, flora and fauna inhabiting the reefs were photographed. Over 900 photos were taken by digital cameras Olympus and Canon. Coefficients of species diversity corals were calculated to Mandaville [7] bythe formula: $\mathbf{H}=-\boldsymbol{\Sigma}\left[\left(\mathbf{n}_{\mathbf{i}} / \mathbf{N}\right) \times\left(\operatorname{lnn}_{\mathbf{i}} / \mathbf{N}\right)\right]$, where $\mathbf{H}-$ Shannon Diversity Index, $\mathbf{n}_{\mathbf{i}}$-number of individuals belonging to i species, $\mathbf{N}$ - total number of individuals), the level of similarity was assessed by Jaccard's index [8]. Cluster analysis of the species composition was performedby Ward's method with Statistica 6, software using original data earlier studies [4,9-11].

\section{RESULTS}

\subsection{Species Richness}

In total, 282 species of mass macroalgae and invertebrates were identified, including 169 species of Scleractinian (Table 1); this is high species abundance for a

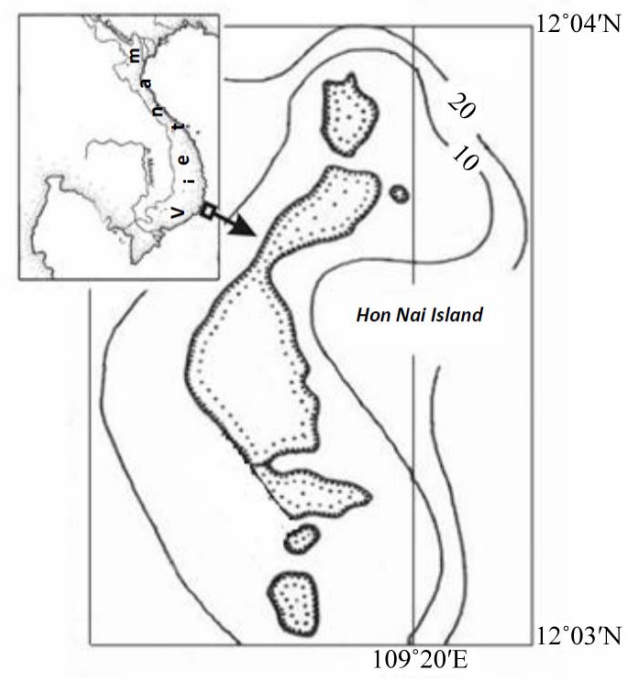

Figure 1. Schematic map of the of Hon Nai Island, a line of transect. small reef of $70 \mathrm{~m}$ wide from the shoreline and $200 \mathrm{~m}$ along the shore line. Suffice it to say that only Acropora counted here some 34 species, which is $80 \%$ of the total composition of these scleractinian on all reefs of Vietnam an donlya quarter of the total abundance of these corals on reefs of the Indo-Pacific [12]. The abundance of these corals indicated favorable conditions on the reef. Acroporids belong to the first organisms that "acrophy to negatively" respond to environmental changes, primarily to anthropogenic pollution and increased eutrophication of the surrounding waters $[1,2,13,14]$. The species diversity of Hon Nai Island reef was comparable to that of reefs of large regions as the Gulf of Siam and the Bay of Tonkin (Figure 2), as well as Con Dao Islands [10].

Thirty-seven species dominated there or were mostly wide-spread: macroalgae Padina australis, Halophyllia ovalis, Alcyonarian Sinularia dura and Sarcophyton trochelioforum, scleractinian Acropora microphthalma, A. nobilis, A.valenciennesi A. verweiy, Montipora aequituberculata, M. hispida, M. grisea, Hydnophorarigida, Porites cylindrica, P. rus, Platygyra daedalia, Leptoria phrigia, Favia speciosa, and Favia camrani sp. nov., mollusks Tridacna crocea, Lambis chiragra, echinoderms Diadema setosum, Holothuria atra, Stihopus chloronatus, Linckia laevigata and O. hpiocoma nigra. Acropora microphthalma and $A$. nobilis form monospecific settlements on the area of up to $100 \mathrm{~m}^{2}$. The both species together with $H$. rigida, $M$. aequituberculata, and $M$. grisea develop dense growths covering $100 \%$ of the substrate over some tens of square meters. Totally, the index of species diversity for Scleractinian was 3.70. The rank order of abundance of different corals along transects and in each zone measured by percentage of the coral coverage is presented in Figures 3 and 4. On the figures it is clear there is predominance of one or two species of Scleractinian coastal reef and ensuring they have a large surface of substrate covering living corals. As the distance from the shore, a growing number of colonies and species of coral and variation of the degree of substrate covering corals.

\subsection{Structure of Communities}

In the coastal part of the reef (reef edge), at a depth of $0.5-1.5 \mathrm{~m}$, a zone of Acropora microphthalma + Hydnophora rigida covered $100 \%$ of the substrate surface for 20 - $40 \mathrm{~m}$. In the zone, Acropora cytherea, A. humilis, Montipora grisea, $M$. hispida, and $M$. vietnam ensis were also wide spread, and separate colonies of Seriatoporahystrix, Stylophora pistilata and Porites lobata occurred. Among Acropora branches, mats of the alga Chnoospora implexa developed. In the coastal zone, a lowest index of species diversity was recorded (1.34) because of the predominance of two species, A. microphthalma and H. rigida (Figure 3(a)). 
Table 1. Distribution of Scleractinian on reef zones.

\begin{tabular}{|c|c|c|c|c|c|c|c|c|c|}
\hline Species & 1 & 2 & 3 & 4 & Species & 1 & 2 & 3 & 4 \\
\hline Acantastreaechinata & - & - & + & - & Favia danae & - & + & + & - \\
\hline A.hemprichii & - & - & - & + & F. favus & - & + & + & - \\
\hline A. hillae & - & - & + & - & F. lizardensis & - & - & + & - \\
\hline Acropora abrolhosensis & - & - & + & - & F. maritima & - & - & + & - \\
\hline A. acuminata & - & + & + & - & F. maxima & - & + & + & + \\
\hline A. anthocercis & - & - & + & - & F. rosaria & - & - & + & - \\
\hline A. austera & + & - & + & - & F. rotumana & - & - & + & - \\
\hline A.brueggemanni & + & + & + & - & F. camranensis sp. nov. & - & - & + & - \\
\hline A. bushyensis & - & - & + & - & F. speciosa & - & + & + & + \\
\hline A. cytherea & + & + & + & + & F. stelligera & - & - & + & - \\
\hline A.digitifera & - & + & + & - & Favites abdita & + & + & + & + \\
\hline A. elengatula & - & - & + & - & Ft. chinensis & - & - & + & - \\
\hline A. florida & - & + & + & - & Ft. complanata & + & - & + & - \\
\hline A. formosa & + & + & + & - & Ft. flexuosa & - & + & + & + \\
\hline A. gemmifera & - & + & + & - & Ft. halicora & - & - & + & - \\
\hline A. glauca & - & + & - & - & Ft. paraflexuosa & - & - & + & - \\
\hline A. grandis & - & - & + & - & Ft. pentagona & - & + & + & - \\
\hline A. hyacinthus & + & + & + & + & Ft. vasta & - & - & + & - \\
\hline A. humilis & + & + & + & - & Fungia costulata & - & - & + & - \\
\hline A. irregularis & - & - & + & - & F. fungites & - & - & + & - \\
\hline A. lamarcki & - & + & - & - & F. granulosa & - & - & + & - \\
\hline A. macrostoma & - & - & + & - & F. scabra & - & - & + & - \\
\hline A. microphthalma & + & + & + & + & F. scruposa & - & - & + & - \\
\hline A. millepora & - & + & + & - & F. scutaria & - & - & + & - \\
\hline A. nasuta & - & - & + & + & Galaxea astreata & - & + & + & - \\
\hline A. nobilis & + & + & + & - & G. fascicularis & + & + & + & + \\
\hline A. ocelata & - & - & + & - & Gardino serisplanulata & - & - & + & + \\
\hline A. polystoma. & - & + & - & - & Goniastrea aspera & + & - & + & - \\
\hline A robusta & + & - & + & - & G. edwardsi & - & - & + & + \\
\hline A. samoensis & - & - & + & - & G. minuta & - & - & + & - \\
\hline A. sarmentosa & - & - & + & - & G. pectinata & + & + & + & - \\
\hline A. schmitti & - & + & - & - & G. retiformis & - & - & + & - \\
\hline A. spicifera & + & + & + & + & Gonioporacolumna & - & - & + & - \\
\hline A. tenuis & - & - & + & - & G. lobata & - & - & + & - \\
\hline A. torresiana & - & + & - & - & G. stokesi & - & - & + & + \\
\hline A. valenciennesi & - & - & - & + & G. stutchburyi & + & + & + & - \\
\hline A. valida & - & + & + & - & Heliopora coerulea & - & - & + & - \\
\hline A. verweyi & - & - & + & - & Herpolitha lima & - & - & + & - \\
\hline Astreopora myriophthalma & + & + & + & + & Hydnophoraexesa & - & + & + & - \\
\hline A. ocellata & - & + & + & - & H. microconos & + & + & + & + \\
\hline Barabattoia mirabilis & - & - & + & + & H. rigida & - & + & + & - \\
\hline Gardinoseris planulata & + & - & + & - & Leptoria phrygia & - & - & + & + \\
\hline Cyphastrea chalcidicum & - & - & + & - & Leptoserisexplanata & - & - & + & - \\
\hline C. microphthalma & - & + & + & + & L. mycetoseroides & - & - & + & - \\
\hline Echinoporahir sutissima & - & - & + & - & L. yabei & - & - & + & - \\
\hline E. lamellosa & + & + & + & - & Lithophyl lonundulatum & - & + & + & - \\
\hline E. gemmacea & - & - & - & + & Lobophyl liaflabelliformis & - & - & + & - \\
\hline Euphylliaancora & + & - & + & - & L. hattaii & - & - & + & - \\
\hline E. divisa & - & - & + & - & L. hemprichii & - & - & + & - \\
\hline E. glabrescens & - & - & + & - & L. robusta & - & - & + & - \\
\hline L. corymbosa & - & - & + & - & P.sinensis & - & - & + & - \\
\hline Montipora aequituberculata & - & - & - & - & Plerogy rasinuosa & - & - & + & - \\
\hline M. angulata & - & + & + & - & Plesiastrea versipora & - & + & + & - \\
\hline M.cactus & - & - & + & - & Pocillopora damicornis & + & + & + & + \\
\hline M. crassituberculata & - & + & + & + & P. eydouxi & - & + & + & - \\
\hline M.danae & + & - & + & - & P. ligulata & - & - & + & - \\
\hline M. digitata & + & + & + & - & P. verrucosa & - & + & + & + \\
\hline M. efflorescens & - & + & - & - & P. woodjonesi & - & + & + & - \\
\hline M. florida & - & + & - & - & Podobacia crustacea & - & - & + & + \\
\hline M. grisea & - & + & + & - & Polyphyllia talpina & - & - & + & - \\
\hline M. hispida & - & + & + & + & Porites attenuata & - & - & + & - \\
\hline M. hoffmeisteri & - & - & + & - & P. australiensis & - & + & + & - \\
\hline M. monasteriata & - & - & + & - & P. cylindrica & + & + & + & + \\
\hline M. porites & - & + & + & - & P. lobata & - & + & + & + \\
\hline M.spongodes & - & - & + & - & P. solida & - & - & + & - \\
\hline M. tuberculosa & - & - & + & + & P. rus & - & + & + & - \\
\hline M. turgescens & - & + & - & - & P. lichen & - & - & + & - \\
\hline
\end{tabular}




\begin{tabular}{|c|c|c|c|c|c|c|c|c|c|}
\hline M. undata & - & - & - & - & P. lutea & - & - & + & - \\
\hline M. verrucosa & - & + & - & - & P. negrosensis & - & + & - & - \\
\hline M. vietnamensis & - & - & + & - & P. nigrescens & + & + & + & + \\
\hline Goniopora columna & - & - & + & - & P. nierstraszi & - & - & + & - \\
\hline M. curta & - & - & + & - & P. superficialis & - & - & + & - \\
\hline M. valenciennesi & - & - & + & + & Psammocora contigua & - & - & + & + \\
\hline Mycedium elephantotus & - & - & + & - & Pseudosiderastrea tayamai & - & + & + & - \\
\hline Oullophyllia crispa & - & - & + & - & Sandalolitha robusta & - & - & + & - \\
\hline Oxypora lacera & - & - & + & - & Seriatopora caliendrum & - & - & + & - \\
\hline Pachyseris rugosa & - & + & + & - & S. hystrix & + & + & + & - \\
\hline P. speciosa & - & + & + & + & Stylophora pistillata & + & + & + & - \\
\hline Hydnophoraexesa & - & - & + & - & Symphyllia agaricia & - & - & + & - \\
\hline Pavona danai & - & - & + & - & S. recta & - & - & + & - \\
\hline P.decussata & - & + & + & - & S. valenciennesii & - & - & + & - \\
\hline Leptoseris explanata & - & - & + & - & Turbinaria peltata & - & - & + & - \\
\hline Platygyra daedalta & - & + & - & - & T. frondens & - & - & + & - \\
\hline P. lamellina & - & + & + & + & & & & & \\
\hline
\end{tabular}

Comments: 1-Zone Acropora microphthalma + Hydnophora rigida; 2-zone Acropora nobilis; 3-zone multispecific settlements; 4 -pre-reef platform.

The zone of Acropora microphthalma + Hydnophorarigida was replaced by the zone of Acropora nobilis, this zone was richer in species variety and extended over $25-30 \mathrm{~m}$ down to a depth of $2.5-3 \mathrm{~m}$. In addition to the dominant species $A$. nobilis, patches of mono settlements were formed here by vast colonies of A. spicifera, A. hyacintus, M. aequituberculata, M. grisea, M. vietnamensis, $H$. rigida, Porites nigrescens, and P. cylindrica, wide spread were large colonies of Pocillopora eudouxi and $P$. woodjonesi (Figure 3(b)). There occurred also the mollusks Lambis chiragra, L scorpius, Trochus niloticus, T. maculates and echinoderms Linckia laevigata, Holothuria atra, and Stichopus chloronatus. The degree of coverage of the substrate with corals was $80 \%$ - $100 \%$. In geomorphological respect, the area looks like alternating bands of the island dacite, according to the extension of the solid rock outcrops. The index of species diversityin the Acropora zone (2.34) was double as high as that in the coastal zone.

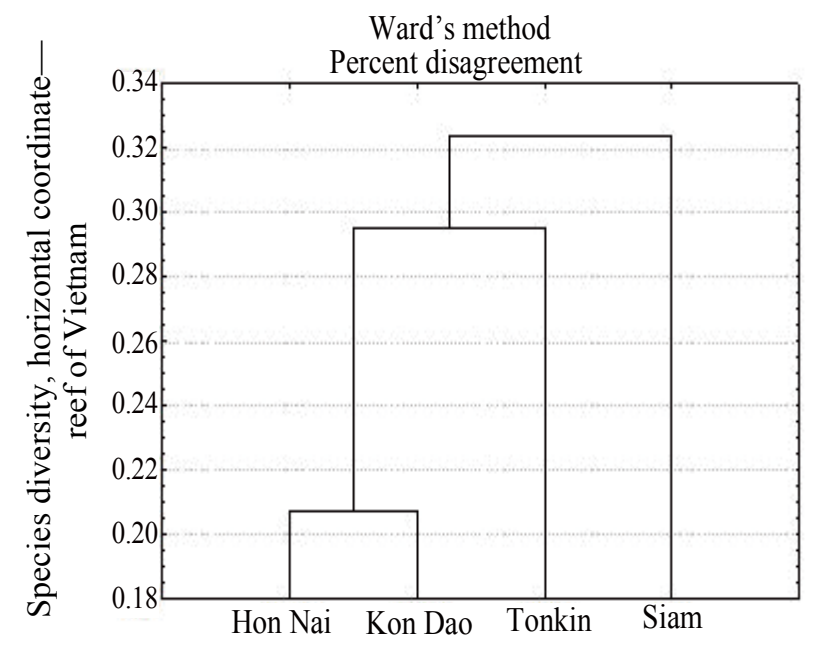

Figure 2. Generic formulations Cluster similarities of Scleractinian species on some reefs of Vietnam.
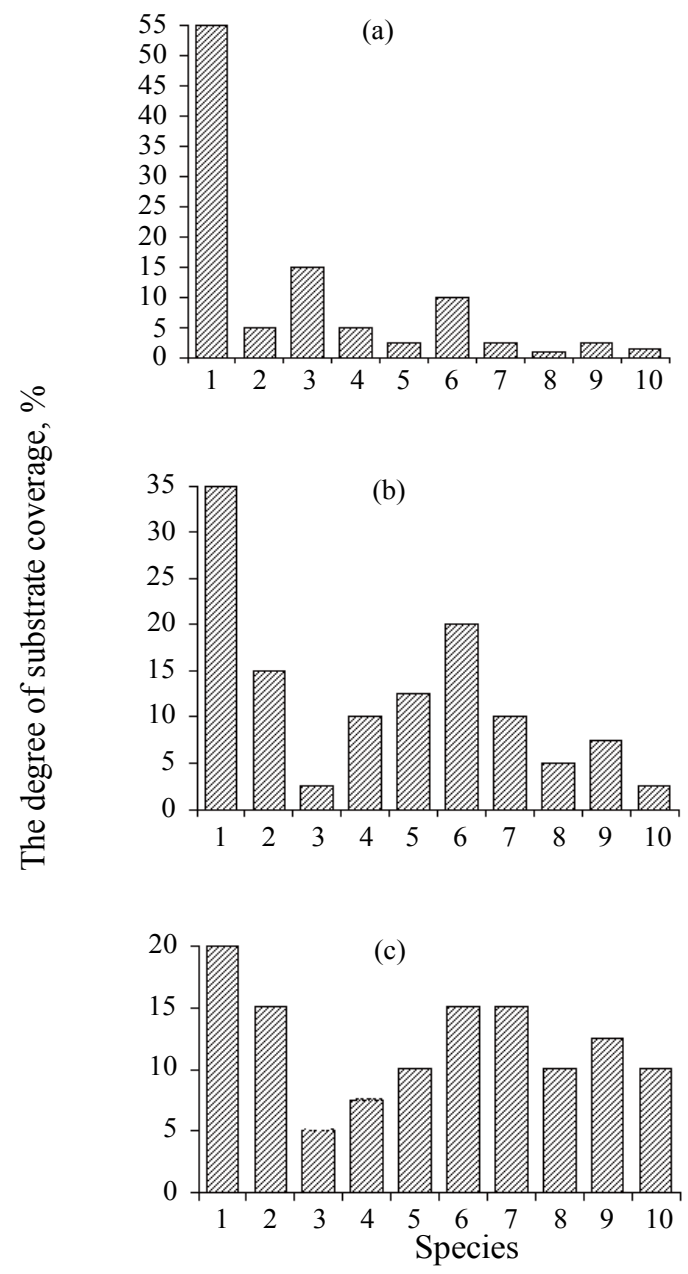

Figure 3. Rank species of Scleractinian, expressed in degrees of covering substrate corals in the various areas of the reef. (a) Zone of Acropora microphthalma + Hidnophorarigida; (b) Zone Acropora nobilis; (c) Zone multispecific settlements of corals. 1: A. microphthalma; 2: A. nobilis; 3: A. valenciennesi; 4: Montipora aequituberculata; 5: M. hispida; 6: Hydnophora rigida; 7: Porites cylindrical; 8: P. rus; 9: Platygyra daedalea; 10: Favia camranensis sp. nov. 


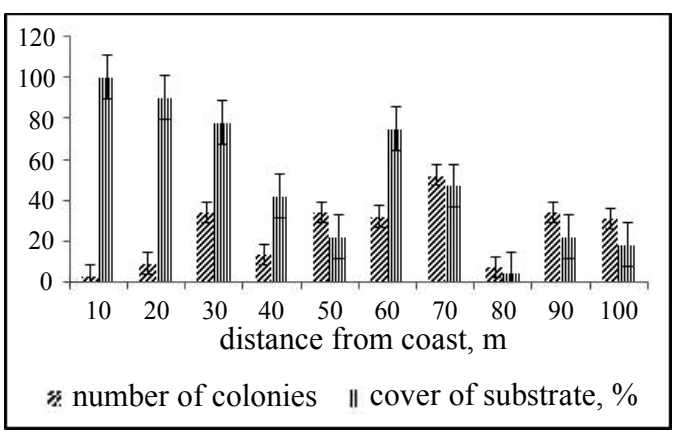

Figure 4. Degree of coral covering substrate and the number of scleractinian colonies at transect.

The zone of multispecific settlements, which is comparable in the species composition and structure of the coral community to the zone of the reef slope of structural reefs, began at a depth of $3 \mathrm{~m}$ and extended over $20-30 \mathrm{~m}$ down to a depth of $6 \mathrm{~m}$. The zone was characterized by a high species richness $(73.49 \%$ of the total composition of Scleractinian species), a wide variety of their colony forms and the highest index of species diversity 3.78 (Figure 5). The author managed to find there corals more than thirty characteristics of sorts of main reefs Indo-Pacific. Of the most frequent occurrence were A. cytherea, A. monticulosa, A. humilis, Porites lobata, P. rus, P. cylindrica, Pocillopora eydouxi, $P$. verrucosa, Platygyra daedalea, $P$. lamellina, Galaxea fascicularis, Merulina ampliata, Lobophyllia hemprihii, and Symphyllia recta, hydroids Millepora dichotoma and M. platyphyla. Fungiids were usually unique; they have been marked only on four sites of their accumulation $4-7$ specimens on plots less than $1 \mathrm{~m}^{2}$, Fungia scutaria, F. scruposa, F. granulosa and Polyphyllia talpina were the most often among them. The degree of substrate coverage with corals varied from $30 \%$ to $75 \%$. Of frequently occurrence were compact settlements of 7 to 30 colonies of different faviid species (Figure 6). From accompanying macrobenthos, most common were Tridacna maxima $\left(0.2 \mathrm{spec} . / \mathrm{m}^{2}\right)$, Lambis hiragra $(0.1 \mathrm{spec} . /$ $\left.\mathrm{m}^{2}\right)$, Trochus niloticus, T. maculatus $\left(0.2 \mathrm{spec} . / \mathrm{m}^{2}\right)$, Diadema setosum (up to $5 \mathrm{spec} . / \mathrm{m}^{2}$ ), Stichopus chloronatus (0.2 spec. $\left./ \mathrm{m}^{2}\right)$, Synapta maculata, and Linckia laviegata, there occurred also single individuals of the sea star Acantaster planci. Massive colonies of Porites and Platygyra were inhabited by polychaetes Spiribranchus giganteus and bivalve mollusks Arca ventricosa ( 3 - $\left.5 \mathrm{spec} . / \mathrm{m}^{2}\right)$, A. navicularis and Barbatia velata. Branched coral colonies support the attached sea lilies Comatula pectinata and Oxycianthu sbennetti. Among coral colonies, the nudibranch mollusks Gymnodoris ceilonica, Phyllidia bourguini, and $P h$. varicosa occur. The reef slope of the major Indo-Pacific reefs, like the zone of poly specific settlements of this reef is characterized by a set of certain coral species and, particularly, by rich species diversity $[9,10$, 15-20].

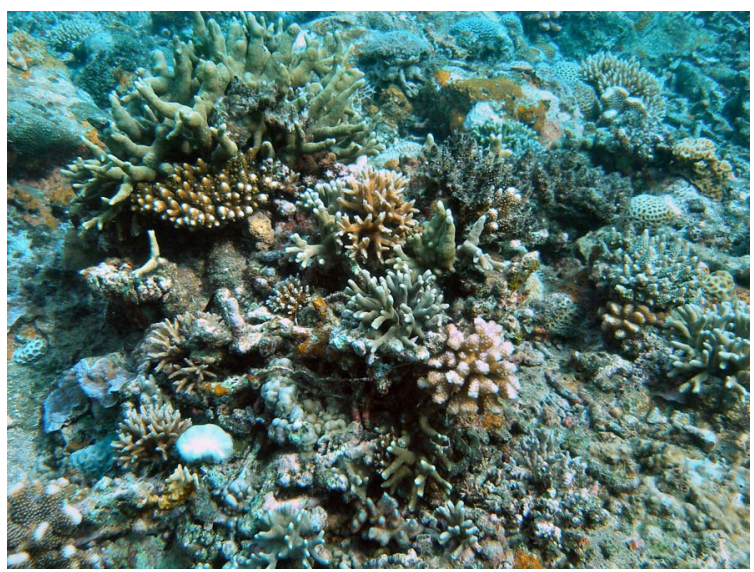

Figure 5. Polispecific settlement, depth $3.5 \mathrm{~m}$.

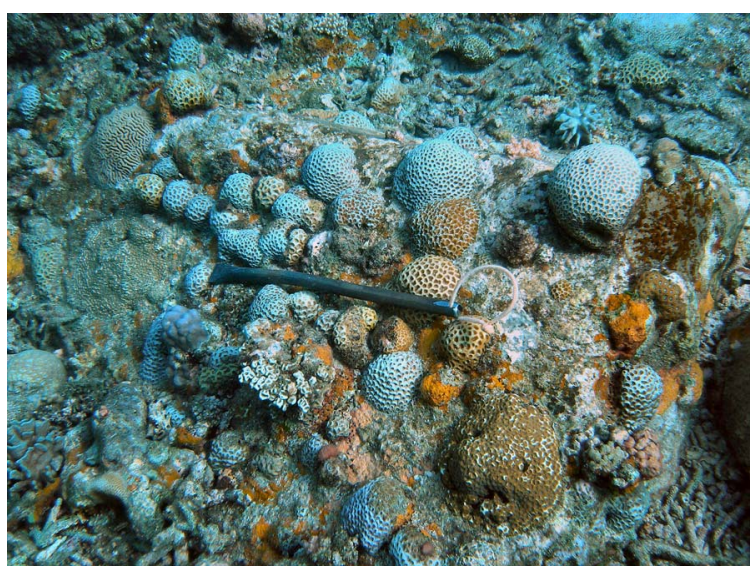

Figure 6. The settlement of Faviidae, depth $4 \mathrm{~m}$.

At a depth of 70 to 100 meters from the coastline, the zone of poly specific settlements transited to a pre-reef platform. This sandy slightly inclined platform with scattered small organogenic blocks was inhabited by colonies of Scleractinian, Alcyonarian and sponges. The number of scleractinian hardly exceeded here 20 species (13.69\% of their species composition on the reef under study). The index of species diversity was 1.3 .

The corallogenous blocks and remnants of dead reefbuilding coral colonies were occupied by single colonies or their settlements of rarely more than five specimens of G. fascicularis, P. lamellina, Goniastrea pectinata, Favia maritima, Porites cylindrica, P. lobata, and Montipora verrucosa. There occurred separate colonies of the Alcyonarian Sinularia polydactila and Lobophytumpauciflorum, hydroids $M$. platyphyla, $M$. dichotoma and the blue coral Heliopora coerulea. Of most frequent occurrence were corals of the first three species G. fascicularis, $P$. lamellina, G. pectinata. The degree of substrate coverage with corals did not exceed 5\% - 7\%. The accompanying macrobenthos was dominated by the sea urchin D. setosum (up to $7-10 \mathrm{spec} . / \mathrm{m}^{2}$ ). The sea stars Culcita novaeguineae, Linckia laevigata and the sponges Cally- 
spongia sp. occurred there occasionally. The branches of gorgonarians and dead corals were inhabited by the mollusks Malleus malleus (up to $0.5 \mathrm{spec} . / \mathrm{m}^{2}$ ) and Isognomonisognomum. Soft sediments were occupied by numerous gastropod mollusks Strombuslu huanus (up to 14 spec. $/ \mathrm{m}^{2}$ ), and occasional burrowing forms of the genera Vasticardium fulvia and Laevicardium sp.

\section{CONCLUSIONS}

By us for the first time have been researched protected optimally preserved reef near densely populated city of Nha Trang and Cam Ranh Bay. The non-structural adjacent reef of Hon Nai Islands is comparable with other reefs of southern Vietnam in morphology, the degree of development of coral structures, qualitative and quantitative composition to corals $[9,11,21,22]$. From 169 scleractinian species found on this reef, $58 \%$ - 69\% werecommon with reefs of the Nha Trang Bay, Con Dao Island, the Gulf of Siam and Tonkin Bay [12,23].

This is a high rate of species richness for very small reef extending just $70-100 \mathrm{~m}$ from the shoreline and stretched a little more than 200 meters along it. Only representatives of the genus Acropora, there are 34 species, representing 80 percent of the total membership of these Scleractinian on reefs throughout Vietnam and a quarter of the total wealth of these corals on reefs Indo-Pacific [12]. The abundance of these corals showed favorable terms on the reef, as it is known that acroporids among the first negatively react to environmental changes, primarily to anthropogenic pollution and eutrophication of the surrounding waters and therefore the first to die, there is no or very few and far between in the contaminated areas $[1,2,13,24]$. The studied reef is characterized by distinct bionomical zonality, high species variety, and dense coral cover on the substrate, mass development of spherical and tabular forms of coral colonies, and continuous monosettlements of acroporids, which is typical for optimal climax conditions on the reef [9,18,25-27].

Bionomical vertical zonality pronounced on the nonstructural reef of Hon Nai Island, like on some other reefs [28,29] was determined presumably by geomorphological peculiarities of the stone-coral substrate of the underwater slope. A similar pattern of vertical bionomiccal zonality corresponding to zonal distribution of environmental factors (substrate, wave mode, degree of sedimentation, illumination) was observed on reefs of the Gulf of Siam [30,31], and different areas of the Pacific and reefs of the Caribbean basin [32,33].

Results of hydrobiological studies coastal Mainland and island reefs of Vietnam in recent years clearly demonstrated their biodegradable, largely due to the intense anthropogenic pressure $[1,24]$. It is hardly possible to exclude wholly the usage of reef resources, therefore, there arise an urgent need for minimizing anthropogenic impact on the ecosystem of the reef, for establishment of new and expansion of the existing marine parks; their fauna and flora shall be fully protected and monitored by groups of scientists capable of detecting changes in the community composition and structure of the coral reef caused by human activity.

Erosion processes along the coastline of the city and port of Nha Trang and the intensification of mariculture operations in many bays of the nearby islands are augmenting sediment fluxes and eutrophication of waters in Nha Trang Bay [2,31]. An increase in the number of macroparticles of various origin causes an increase in the turbidity of the sediment, reduces the photosynthetic capacity of reef-building corals and other benthic organisms, and influences some physical and biological processes in these organisms. A decrease in species diversity of corals, the degree of coral cover, and growth rates with an increase in sediment amounts has been demonstrated by numerous studies [14,31]. On the other hand, this can be accompanied by an increase in the degree of substrate cover by macrophytes [2]. Untreated sewage waters and wastes from mariculture farms as dissolved and undissolved particles bring subsidiary nutrients as well as noxious substances into the water column and bottom sediments [16]. The different changes in coral communities on the reefs of the Mju and other Moon Islands provide an obvious example of differentiated anthropogenic impact. The reefs of Mju Island are located in close proximity to the city and port of Nha Trang. Moon Island lies farther from the city; its reefs are in the protected reserve zone, and its inhabitants are the small staff of the cordon and reserve administration. Water transparency and water exchange over coral settlements of Mju Island are 1.48 times lower, and sediment flux per day is 1.3 times higher, than in the case of Moon Island [2]. Ever-increasing anthropogenic pressure is leading to the eutrophication of the waters washing Mju Island and to increased silt content in the sediment. As a result, the degree of substrate cover by corals decreases, and that by macrophytes increases. There is a reduction in the biodiversity of reef-building corals and attendant common species of macrobenthos. Because of the high content of particulate suspended material in this locality (1.3 times higher than in other areas), the Acropora species that earlier dominated the reefs of Mju Island have been replaced by thin branched Montipora, which appear to be more tolerant of siltation.

The main strategy of the Government's activity should be aimed at protection of the reef's resources. The protection measures should involve, on one hand, regulation of economic activity, and on the other hand, abroad explanation to the local population, fishermen and tourists of the real threat of destruction of reefs and the degradation of their resources, in order to impart them conscious 
and careful attitude to the reefs as national and global heritage. The experience shows that any restrictive measures do not have an effective influence on protection and rational use without broad out reach and care of residents themselves for their heritage.

Theses expansion of protective measures and minimization of human influence on some reefs of Vietnam (Mun Island, Bach Long Vi and Con Dao Islands) immediately affected the state of reefs. It has been established that their ecological condition has improved markedly: the species diversity in the areas has not diminished over the past five years, and significantly exceeds that on the adjacent unprotected reefs $[11,24,34]$. The example of the reef of Hon Nai Islands protected by the company Sanest is a convincing proof of the positive effect on the health of the reef.

\section{AKNOWLEDGEMENTS}

The authors sincerely thank administration of Nha Trang Institute of Technology, Research and Application and personally Dr. Bui Minh Ly, Director of the Institute, for their support of our research and appreciate the help of Irina Barsegova for translating the manuscript into English and Dr. Nikolai Selin for the help in work and definition of mollusks. I am also grateful anonymous reviewer for its constructive comments and tips.

\section{REFERENCES}

[1] Pavlov, D.S., Smurov, A.V., Ilyash, L.V., et al. (2004) Present-day state of coral reefs in Nha Trang Bay (southern Vietnam) and possible reasons for the disturbance of scleractinian habitats. Russian Journal of Marine Biology, 30, 60-67. doi:10.1023/B:RUMB.0000020568.41920.e2

[2] Latypov, Y.Ya. (2006) Changes in the composition and structure of coral communities of Mju and Moon Islands, Nha Trang Bay, South China Sea. Russian Journal of Marine Biology, 32, 269-275. doi:10.1134/S1063074006050014

[3] Wainwright, S.A. (1965) Reef communities visited by the Israel South Red Sea expedition, 1962. Bulletin of Sea Fish Station Israel, 38, 40-53.

[4] Latypov, Y.Ya.(1995) Community structure of scleractinian reefs in the Baitylong Archipelago (South China Sea). Asian Marine Biology, 12, 27-37.

[5] Petersen, C.G.J. (1915) Valuation of the Sea. II. The animal communities of the sea bottom and their importance for marine zoogeography. Report Danish Biology Station, 21, 1-67.

[6] Loya, Y. and Slobodkin, L.B. (1971) The coral reefs of Elate (Gulf of Elate, Red Sea). Journal Sample Zoological Society of London, 28, 117-140.

[7] Mandaville, S.M. (2002) Benthic macroinvertebrates in freshwater-Taxa tolerance values, metrics, and protocols, project H-1. Soil \& Water Conservation Society of Metro Halifax, Nova Scotia.
[8] Jaccard, P. (1902) Lois de destributionflorale dans la zone alpine. Bulletin Société Vaudoise des Sciences Naturelles, 38, 69-130.

[9] Latypov, Y.Ya. (1993) Benthic communities of the coral reefs of the Kondao Islands in South-China Sea. Russian Journal of Marine Biology, 19, 310-318.

[10] Latypov, Y.Ya. (2007) Korallovye reefy Vietnama. M. Nauka.

[11] Latypov, Y.Ya. (2008) Species composition and structure of coral community of a platform reef at Bach Long Vi Island in the South China Sea. Russian Journal of Marine Biology, 34, 249-253. doi:10.1134/S1063074008040068

[12] Latypov, Yu.Y. and Long, P.Q. (2010) The common hard corals of Vietnam. Ministry of Agriculture and Rural Development, Hanoi.

[13] Cortes, J. and Risk, M.-J. (1985) A reef under siltation stress: Cahuita, Costa Rica. Bulletin of Marine Science, 36, 339-356.

[14] Tomascik, T. and Sander, F. (1987) Effects of eutrophication on reef corals. II. Structure of scleractinian coral communities on fringing reefs, Barbados, West Indies. Marine Biology, 94, 53-75. doi:10.1007/BF00392900

[15] Loya, Y. (1972) Community structure and species diversity of hermatypic corals at Eilat, Red Sea. Marine Biology, 13, 100-113. doi:10.1007/BF00366561

[16] Pichon, M. (1974) Dynamics of benthic communities in the coral reefs of Tule'ar (Madagascar): Succession and transformation of the biotopes through reef tract evolution. Proceeding of 2nd International Coral Reef Symposium, Brisbane, 2, 55-68.

[17] Bouchon, C. (1981) Quantitative study of the Scleractinian coral communities of a fringing reef of Reunion Islands (Indian Ocean). Marine Ecology, 4, 273-288.

[18] Sheppard, C.R.C. (1982) Coral population on reef slopes and their major controls. Marine Ecology Progress Series, 7, 83-115. doi:10.3354/meps007083

[19] Latypov, Y.Ya. (1982) Species composition and distribution of scleractinian in reefs of the Khanh Hoa province (South Vietnam). Biologia Morya, 6, 5-12.

[20] Latypov, Y.Ya. (1987) Scleractinian corals of South Vietnam. The Soviet Journal Marine Biology, 13, 246-252.

[21] Latypov, Y.Ya. (2000) Macrobenthos communities of coral reefs of the an thoi archipelago, South China Sea. Russian Journal of Marine Biology, 26, S25-S26. doi:10.1007/BF02759489

[22] Latypov, Y.Ya. (2003) Reef-building corals and reefs of Vietnam.1. The Gulf of Siam. Russian Journal of Marine Biology, 29, S22-S33. doi:10.1023/B:RUMB.0000011714.71499.75

[23] Latypov, Y.Ya. (2011) Scleractinian corals and reefs of Vietnam as a part of the pacific reef ecosystem. Open Journal of Marine Science, 1, 50-68. doi:10.4236/ojms.2011.12006

[24] Latypov, Y.Ya. (2006) Changes in the composition and structure of coral communities of Mju and Moon Islands, Nha Trang Bay, South China Sea. Russian Journal of Marine Biology, 32, 269-275. 


\section{doi:10.1134/S1063074006050014}

[25] Grigg, R.W. and Maragos, J.E. (1974) Recolonization of corals on lava in Hawaii. Ecology, 55, 387-395. doi: $10.2307 / 1935226$

[26] Mergner, H. (1979) Quantitative okologische Analyseeines Rifflagunenarealsbei Aqaba (Golf von Aqaba. Rotes Meer). Helgoland Wissenschaft Meeresuntersuch, 32, 476507. doi:10.1007/BF02277991

[27] Pichon, M. (1981) Dynamic aspects of coral reef benthic structures and zonation. Proceeding 4th International Coral Reef Symposium, 1, 581-594.

[28] Jones, O.A., Randall, Y.M., Cheng, H.T., et al. (1972) A marine biological survey of southern Taiwan with emphasis on corals and fishes. Institute Oceanography $\mathrm{Na}$ ture Taiwan University Special Publicution, 1, 1-93.

[29] Dai, C.F. (1993) Patterns of coral distribution and benthic space partitioning on the fringing reefs of Southern Taiwan. Marine Ecology, 14, 185-203. doi:10.1111/j.1439-0485.1993.tb00479.x

[30] Latypov, Y.Ya. (1986) Coral communities of the Namsu Islands (Gulf of Siam, South China Sea). Marine Ecology Progress Series, 29, 261-270. doi:10.3354/meps029261

[31] Sakai, K., Yeemin, T., Svidvong, A. et al. (1986) Distribution and community structure of hermatypic corals in the Sichang Islands, inner part of the Gulf of Thailand. Galaxea, 5, 27-74.

[32] Lang, J. (1974) Zonation at the base of a reef. American Science, 62, 272-281.

[33] Liddel, W.D. and Ohlhorst, S.L. (1987) Patterns of reef coral community structure, North Jamaica. Bulletin ofBioljgy, 40, 311-329.

[34] Latypov, Y.Ya. and Selin, N. (2011) Current status of coral reefs of islands in the Gulf of Siam and southern Vietnam. Russian Journal of Marine Biology, 37, 246253. doi:10.1134/S1063074011040080 